Ingrid Lyngved Ødegård

ingrid.lyngved.odegard@sykehuset-innlandet.no Anestesiavdelingen

Sykehuset Innlandet Lillehammer

2609 Lillehammer

\section{Kolbjørn Høgåsen}

\section{Dag Paulsen}

Nyreseksjonen

Medisinsk avdeling

Sykehuset Innlandet Lillehammer

\section{Helge Scott}

Patologisk avdeling

Oslo universitetssykehus, Rikshospitalet

\section{Oppgitte interessekonflikter: Ingen}

\section{Litteratur}

1. Cacoub P, Fabiani FL, Musset L. Mixed cryglobulinemia and hepatitis $C$ virus. Am J Med 1994: 96 : 124-32

2. Kamar N, Rostaing $L$, Alric L. Treatment of hepatitis C-virus-related glomerulonephritt. Kidney Int 2006; 69: 436-9.
3. Campise M, Tarantino A. Glomerulonephritis in mixed cryoglobulinaemia: what treatment. Nephrol Dial Transplant 1999; 14: $281-3$.

4. Mazzaro C, Pozzato G, Zorat F et al. Etiologic treatment of hepatitis $C$ virus-associated mixed cryoglobulinemia. Dig Liver Dis 2007; 39 (suppl 1): $102-8$

5. Johnson RJ, Gretch DR, Yamabe $\mathrm{H}$ et al. Membranoproliferativ glomerulonephritis associated with hepatitis C virus infection. N Engl J Med 1993: 18 . 465-70.

6. Roccatello D, Fornasieri A, Giachino 0 et al. Multicenter study on hepatitis $C$ virus-related cryoglobulinemic glomerulonephritis. Am J Kidney Dis 2007: 49: 69-82

7. Roithinger FX, Allinger S, Kirchgatterer A et al A Lethal course of chronic hepatitis C, glomerulonephritis and pulmonary vaskulitis unresponsive to interferon treatment. Am J Gastroenterol 1995; 90: $1006-8$

8. Gomez-Tello V, Onoro-Canaveral JJ, de la Casa Monje RM et al. Diffuse recidivant alveolar hemorrhage in a patient with hepatitis $\mathrm{C}$ virus-related mixed cryoglobulinemia. Intensive Care Med 1999. 25: $319-22$.

9. Suzuki R, Morita H, Komukai D et al. Mixed cryoglobulinemi due to chronic hepatitis $\mathrm{C}$ with severe pulmonary involvement. Intern Med 2003. 12: $1210-4$

10. Chejfec G, Lichtenberg L, Lertratanakul Y. Respiratory insufficiency in a patient with mixed cryoglobulinemi. Ultrastruct Pathol 1981; 2: 295-302.

11. Stagg M, Lauber J, Michalski MD. Mixed essential cryoglobulinemia and adult respiratory distress syndrome: a case report. Am J Med 1989; 87: 445-8

12. Garini G, Allegri L, lannuzzella F et al. HCV-related cryoglobulinemic glomerulonephritis: implications of antiviral and immunosuppressive therapies. Acta Biomed 2007; 78: 51-9

13. Jara LJ, Vera-Lastra O, Calleja MC. Pulmonaryrenal vasculitic disorders: differential diagnosis and management. Curr Rheumatol Rep 2003; 5 $107-15$.

Manuskriptet ble mottatt 29.1. 2009 og godkjent 30.7. 2009. Medisinsk redaktør Anne Kveim Lie.

\title{
Når det åpenbare ikke er det vanlige
}

Det er anslått at opptil 30000 personer kan være infisert med Hepatitt $\mathrm{C}$ i Norge (1). Viruset er kjent for sine hepatotrope egenskaper med fare for utvikling av kronisk hepatitt, levercirrhose og hepatocellulært karsinom, men det er mindre kjent at viruset kan medfører en del ekstrahepatiske manifestasjoner (2). De fleste av disse er autoimmune sykdommer, som tenkes utløst enten av stimulering av autoreaktive B-celler ved vedvarende virale proteiner eller via en direkte lymfotrop effekt av selve viruset. Kryoglobuliner er det hyppigste biologiske funn og påvises hos $50-60 \%$, mens antinukleære antistoffer $(40 \%)$, revmatoid faktor $(29 \%)$ og antiglatt muskulatur-antistoffer $(10 \%)$ også er frekvente funn (3). Til tross for dette utvikler bare en mindre del av pasienter manifest ekstrahepatisk sykdom som artralgier, siccasyndrom, nevropati, vaskulitt, tyreoiditt og lymfom (3). Kryoglobuliner er immunglobuliner (Ig) som kjennetegnes ved at de ikke lenger er løselige ved temperaturer lavere enn kroppstemperatur, og at de kan løses opp igjen ved oppvarming av serum (4). Påvisning av kryoglobuliner er krevende siden ukorrekt prøvehåndtering (f.eks. nedkjøling ved lang transport) kan ødelegge proteiner. Om kryoglobulinemi vil føre til nedslag av kryoglobuliner i kroppen og utløse en inflammasjonstilstand, er avhengig av mengden av kryoglobuliner og sammensetningen. Analyse ved hjelp av immunofiksasjon kan vise om de består av et monoklonalt Ig (definert som type I kryoglobulinemi; oftest sett ved plasmacelledyskrasier) eller en kombinasjon av et monoklonalt (spesielt av IgM type) og polyklo- nalt Ig (definert som type II eller blandet kryoglobulinemi (4).

I den beskrevne kasuistikken utviklet pasienten en vaskulittilstand assosiert med blandet kryoglobulinemi, noen måneder etter at hun fikk påvist hepatitt C-antistoffer. Kryoglobulinassosiert småkarsvaskulitt forekommer som selvstendig autoimmun sykdom, men er oftest (60-80\%) relatert til hepatitt $\mathrm{C}$-infeksjon. Likevel utvikler ikke mer enn $2-4 \%$ av pasienter med hepatitt $C$ (3) slik småkarsvaskulitt, og det er sjelden at forløpet blir så alvorlig. Kasuistikken er dermed interessant i seg selv, men byr ellers på flere læringsmomenter.

Pasienten hadde nydebuterte små, ømme hevelser på leggene, som mest sannsynlig representerte enten erythema nodosum (fettvevsnekrose) eller purpura allerede ved innleggelse. Det er uklart om og hvordan disse lesjoner ble tolket, men at viktige funn i huden på uforklarlig vis blir oversett, er en kjent diagnostisk fallgruve ved inflammatoriske systemsykdommer. Pasienten hadde ellers nedsatt nyrefunksjon, uttalt hypalbuminemi med fortsatt moderat proteinuri samt hematuri. Nærmere en klinisk beskrivelse av glomerulonefritt kommer man neppe. At det endelige beviset for glomerulær affeksjon ved funn av cellesylindre kom først etter at urinmikroskopering ble gjentatt av mer erfaren fagfolk, viser hvor viktig opplæring og erfaring med urinmikroskopering er.

Pasienten ble behandlet med et tredjegenerasjons kefalosporinpreparat, selv om det ikke forelå åpenbare kliniske tegn til pneumoni, urinveisinfeksjon eller sepsis.
Dette passer dårlig med anbefalinger om fornuftig bruk av antibiotika i sykehus (5) og bidro til at de åpenbare tegnene på den bakenforliggende systemisk inflammatoriske sykdommen lenge ble oversett. Når det åpenbare ikke stemmer med det vanlige, er det - også $i$ travle hverdager indisert med en kort tenkepause. Dette kunne ha spart pasienten for en Clostridium difficile-infeksjon, og etter all sannsynlighet også for utvikling av hemoragisk alveolitt under sykehusoppholdet.

\section{Johannes Cornelis Nossent}

hans.nossent@unn.no

Revmatologisk avdeling

Universitetssykehuset Nord-Norge

9038 Tromsø

\section{Oppgitte interessekonflikter: Ingen}

\section{Litteratur}

1. Vik IS, Skaug K, Dalgard O et al. Hepatitt C et helseproblem også i Norge. Tidsskr Nor Legeforen 2008; 128: 563-6.

2. Kristiansen MG. Florholmen J. Ekstrahepatiske manifestasjoner ved hepatitt C-infeksjon. Blir de oversett? Tidsskr Nor Lægeforen 2001; 121 $446-9$

3. Cacoub P Renou C. Rosenthal E et al. Extrahepatic manifestations associated with hepatitis $C$ virus infection. A prospective multicenter study of 321 patients. The GERMIVIC. Groupe d'Etude et de Recherche en Medecine Interne et Maladies Infectieuses sur le Virus de l'Hepatite C. Medicine (Baltimore) 2000; 79: 47-56.

4. Ferri C, Mascia MT. Cryoglobulinemic vasculitis Curr Opin Rheumatol 2006; 18: 54-63.

5. Berild D, Haug JB. Fornuftig bruk av antibiotika i sykehus. Tidsskr Nor Legeforen 2008; 128: 2335-9. 